\title{
Shifts in Global Security Policies: Why They Matter for the South
}

\author{
Susan L. Woodward"
}

Abstract The global security order has been evolving since 1989 , led initially by the USA to expand its post1945 order in Europe to the rest of the world but propelled as well by competition and debates within that post-Second World War alliance, as collective victors in the Cold War, about how to define a new international order. This article identifies three US policies that began this restructuring; their parallel redefinitions of security, and the tensions provoked by this agenda and its consequences, both within the 'North', replacing the 'West', between North and 'South', replacing the 'East' and the resulting multiple opportunities for alternative political coalitions, North against South, between North and South, and within the South, that have yet to play themselves out fully. The resulting fluidity has not yet stabilised into a new international security order.

Is the international order since 1989 a continuation of the order crafted by the USA after the Second World War? Or did the many efforts in the early 1990 s to seize on the 'peace dividend' to create an order based on cooperative over collective security, human security over state security, and new multilateralism led by an unleashed UN, transform global security 'toward a new world order', as even US President George H.W. Bush proposed in an address to a joint session of the US Congress on 11 September 1990?

In After Victory, John Ikenberry argues that any international order is shaped by victory in major war and what the victorious states do with their 'newly acquired power'. If they seek to keep that power by, 'paradoxically' finding ways 'to set limits on their power and make it acceptable to other states' and bind themselves 'to long-term commitments' (Ikenberry 2001: xi), that order will be stable. For Ikenberry, the victors in 1989, the USA and its Western allies, did initially follow this principle. More than a decade after, the result was a 'remarkable durability of the 1945 order among the industrial democracies despite the end of the Cold War' (Ikenberry 2001: 257).

The unilateralism of the George W. Bush Administration in the next decade, 2001-8, including its repeated refusal to be bound by long-term commitments, including treaties signed, ${ }^{2}$ would suggest instead a major break. Analysts and citizens in many parts of the world, such as the Middle East and Latin America, began to argue openly that the USA had become the greatest threat to global security, not its hegemonic stabiliser. That the US

Administration had company in many of those actions, whether in Iraq and Afghanistan or its policy on Israel and Palestine, from some or all of its post-1945 NATO allies, in contrast, would seem to support the Ikenberry assessment.

This apparent contradiction between US unilateralism in 2001-8 and the support for US policies, however grudgingly, by its allies of 1945 and 1989 is viewed by other scholars, such as Mark Duffield and Rita Abrahamsen, as demonstrating a new global order. No longer based on a single hegemon but on an organised system of hegemony, this post-1989 order is far more reminiscent of nineteenth-century colonialism in which the wealthy states of the North, according to Duffield, now use humanitarian and development assistance in addition to military power to ensure their own security ('the Western way of life', Duffield 2007: 2) against threats from the South. 
This article takes the position that it is too soon to say what the post-1989 global security order is, despite nearly two decades of global restructuring. As Ikenberry predicted, the first phase of redefinition was a contest among the victors, the USA and its post-1945 allies, over how to institutionalise their newly acquired power. Francis Fukuyama proved wrong from the very start that 1989 was an 'end to history' (Fukuyama 1989). This contest took place in Europe, but it was soon superseded by a new polarity. North and South replaced East and West, and Northern policies toward the South do appear to be defensively motivated in a transformative agenda, whether as 'counterinsurgency' (Duffield 2001), 'disciplining' (Abrahamsen 2000), or value change (Jervis 2002).

At the same time, the particular policies chosen by the Bush Administration at the critical juncture of 1989-90 both provoked challenges to Northern hegemony and resulted in greater heterogeneity in the South. The tensions between the Northern agenda and Southern states, on the one hand, and the new opportunities for alternative political coalitions within the South and between some Southern states and the North, on the other, make this a very fluid environment. Whether some new multipolarity of unknown stabilising mechanisms results or, as Ikenberry would argue, the postwar victors find a way to make their new order acceptable to the rest, is difficult to predict.

This article will propose instead to identify three trends in the evolution of a new security order and some of the tensions and differentiation they have provoked, beginning with the policies of US President George H.W. Bush, in the flush of Western triumphalism of 1989 and the goal of maintaining the post-1945 order under the new conditions. I label these 'allies from within', the 'new regionalism' and 'rogue states and failed states'.

\section{Allies from within}

The victory of 1989 was economic and political, not military. The end of the Soviet Union and communist power in Eastern Europe was a victory for capitalism as a world system. Fukuyama's claim was that it was also a victory for 'liberal democracy as the final form of human governance'. Yet to extend the principles of the order that the USA created in Western Europe after 1945 to the rest of the globe required radical transformation of the domestic orders of all those countries that had been socialist or retained the capacity for alternative policies. The goal, as the president of the World Bank at the time, Barber Conable, said in a speech to open the Bank's annual conference on development economics in September 1991, '[i]f we are to achieve development, we must aim for growth that cannot be easily reversed through the political process of imperfect governance' (cited in Doornbos 2003: 8). The faster the pace of change, the less opportunity for political resistance, as the International Monetary Fund (IMF), World Bank and USAID staff explicitly argued at the time in the cases of Eastern Europe and the former Soviet Union to explain 'shock therapy' and rapid privatisation of stateowned assets before the apparently necessary institutions could be created.

These policies had an explicit security dimension. As Leo Panitch and Sam Gindin argue in regard to the original model, the USA after 1945 did not create an empire in the nineteenth century sense, particularly as portrayed by theorists of imperialism, but would instead create 'allies from within' (Panitch and Gindin 2004). The Marshall Plan would use US aid and political conditionality to influence changes in the domestic institutions and policies of European countries in such a way that the countries' own interests would become naturally aligned with US economic interests. NATO would then gather these economic allies into a 'transatlantic community' of collective security, defined as much by the values it protected as the states' territory.

The first phase of this policy occurred in Eastern Europe, and it had an advantage in that post1945 order. The USA could get the European Union (EU) and NATO to perform this task of transformation - elsewhere it would have to rely on the IMF, World Bank and World Trade Organization (WTO). Yet even in this first phase, the allies' common economic and security interests were not enough to override their competing national interests. US businesses met stiff competition from European businesses, particularly German investors, in Eastern Europe, Russia and the post-Soviet republics. Most EU member states aside from the UK (based on national interest toward the EU, not 
its 'special relationship' with the USA) resisted enlargement for almost a decade, and they still resist US pressure in regard to the western Balkans and Turkey. European efforts to change European security architecture in order to act early towards Yugoslavia in 1990-1, by contrast, was resisted by President Bush, who opposed the extension of Article $\mathrm{V}$ guarantees beyond NATO's 1990 borders and, along with the USSR, any action by the Helsinki Conference on Security and Cooperation in Europe (CSCE) as well. EU reluctance on enlargement and US insistence on retaining dominance over European security began to break down in 1994 under President William J. Clinton under pressure from Poland to use NATO membership as leverage to EU membership. By the end of the decade, however, these disputes appeared to have been led by friction among allies with common systemic interests: Poland was a member of the EU, and NATO was acting globally to implement US policy in Kosovo, Afghanistan, the Indian Ocean and beyond.

Although there were no comparable regional allies to carry out domestic transformation in the rest of the world, this disadvantage was eased by a new advantage. With economic and political reform and then the collapse of the Soviet Union, the source of financial or military support for alternative economic policies and security alliances in the global South was gone. The structural constraints of global capital were already seeing the domestic effects by the early 1990s, such as in Mozambique, Zimbabwe, South Africa, India and Brazil, with financial assistance and conditions from international financial institutions (IFIs) and Western donors. The power of IFIs and Western donors over policies in the South was extended from the orthodox macroeconomic stabilisation and structural adjustment policies of the 1980s and the goal of imposing agencies of restraint on domestic economic policies to political reform under the label of 'good governance' and democratic participation. This neoliberal consolidation has had potentially profound effects on the global South: while some now had the trade power and economic interest to join with Northern states, as in the G20, or to bargain collectively in the South, as in the Doha Trade Round, or as foreign investors like IBSA, ${ }^{3}$ many others were consumed by civil war or what the North terms as 'state failure'.

\section{The new regionalism}

The second US policy, proposed by George H.W. Bush in Ankara in July 1991, was the security component of postwar policy toward the nonEuropean, non-NATO part of the world: a new regionalism. Global security would now be based on a 'hub and spokes' of regional organisations and powers that were US allies and would accept ever larger financial and organisational responsibility for implementing a still US-led global order. Bush's hopeful reference in 'Toward a New World Order' to a UN that would be freed from Cold War politics (the threat of Soviet veto and resistance to US policies from non-aligned powers) to play the role in international peace and security envisioned at San Francisco, can be seen as prelude to this policy. The Security Council did, indeed, approve a cascade of UN activism in peacemaking and peacebuilding, beginning in 1989-90, while the USA refused to provide its own soldiers or pay its dues until 1999. The costs of peacekeeping operations and military capacities would be outsourced to regional organisations. The US remains the obstacle to any change in financing for peacekeeping operations away from unpredictable voluntary contributions to a more reliable budgetary base in member-state assessments.

Growing US frustration with opposition from the non-aligned caucus at the UN during the 1990s and then, along with its European allies, the refusal of non-European powers - Russia, China and India especially - to sanction military intervention in Kosovo in 1999, however, revived tensions between the USA and the UN and inspired hopeful prospects for UN reform and financing. The concept of the new regionalism appears to have won instead. The EU has developed rapid reaction and crisis management capacities, the USA and some allies have been actively strengthening the security capabilities of the African Union (AU) and ECOWAS is to assume ever more of the burden of peace operations in Africa, and even those most committed to the principle of non-intervention have now lowered the bar significantly to Security Council approval only. Russian troops participated in Croatia, Bosnia-Herzegovina and Kosovo; China is the one of the largest contributors to UN peacekeeping missions globally and the largest of the Permanent Five; and military forces from Brazil, Argentina and Chile even led the UN stabilisation mission in Haiti for the USA. 
The new regionalism has its economic complement in the growing emphasis on regional trade pacts, and places where regional powers are strong, such as South Africa and the New Partnership for Africa's Development (NEPAD) or the Brazilian-initiated Union de Naciones del Sur (UNASUR) have increasingly linked development and security for regional conflict management as well as defence cooperation. Even India signed a new defence pact with the USA in 2008 that included regional responsibilities.

\section{Rogue states and failed states}

While the USA moved to extend its post-1945 economic and security order to the rest of the world after 1989, it was not so clear what the USA would now do militarily as the 'sole remaining superpower' with a defence establishment organised entirely around a vanished Soviet threat. Arms control circles in the USA and Western Europe seized early on the opportunity to argue for a shift from collective security of blocs to cooperative security based on the CSCE. By 1994, the United Nations Development Programme (UNDP) was urging an even more radical shift in security by dedicating its annual Human Development Report to a new concept - human security - to replace military budgets for the defence of states and territory, with its extraordinary waste on stockpiles of armaments and standing armies, with aid to economic and social development focused on individuals and their rights to social and economic security. ${ }^{4}$

Within the US government, in contrast, as Michael Klare has revealed, the former chairman of President Bush's Joint Chiefs of Staff, General Colin Powell, realised already with the events in Hungary in August 1989 and before that he had 'to construct a new threat scenario to justify the preservation of America's superpower capabilities in a world devoid of a prime adversary' (Klare 1998: 12). First presented to President Bush on 15 November 1989, Powell's new, post-Soviet strategy argued for a shift to 'rising Third World powers', and in President Bush's formal announcement the next year, on 2 August 1990, that 'America must possess forces able to respond to threats in whatever corner of the globe they may occur'. Powell labelled these rising powers 'rogue states'. The threat of 'rogue leaders' was further refined under the Clinton Administration as 'leaders set on regional domination through military aggression' (Secretary of Defence Les Aspin) and as those who 'not only choose to remain outside the family of nations but also assault its basic values' (National Security Advisor Anthony Lake) and cause nuclear proliferation (Klare 1998: 12-14).

Amidst these debates about the redefinition of security and the use of military force, the actual pressures for military intervention in the 1990s came from civil wars and humanitarian emergencies, rather than Washington's focus on rogue states or alternatives promoting human security. The humanitarian community thus called for the redeployment of US and allied military assets to intervene more effectively and often in humanitarian emergencies; intentions were to establish an international obligation to intervene (a devoir d'ingérence according to its proponent, Bernard Kouchner) and build on the growing public awareness of and horror at the human cost of the wars in Somalia and Bosnia, among others. UN High Commissioner for Refugees, Sadako Ogata, added to this a 'right to stay' in their home country for the internally displaced and potential refugees in place of seeking asylum in a third country, but which would require international intervention to protect civilians during wartime. The human rights community succeeded, against US opposition, in winning a ban on antipersonnel land mines on the grounds of human security, as well as new instruments to enforce the laws of war, such as the International Criminal Court. Even development agencies, from USAID to the World Bank, introduced the link between security and development and the 'real global threat' of failed states, including consequences, such as civil conflicts and destabilising refugee flows (Atwood 1994).

Although two security threats competing for use of military power, 'rogue states' and 'failed states', differed substantially in their assumptions about intervention and their advocates, they both represent a North-South polarity. The debates were among Northern states and actors whereas the objects of intervention, whether for development or security, were in the South. Although states in the global South introduced the concept of 'nontraditional security' and attempted to insert their concerns into the global agenda, such as energy security, cultural security, environmental 
security, and so forth, the debate remained focused in the North. In relation to the multiple challenges emerging within this debate and resulting policies to US security doctrine, the evolution of Norway and Canada away from the developmental basis of human security is particularly revealing.

In May 1998, the two countries joined forces in Lysøen, Norway, to convene a group of likeminded middle powers, including Japan, ${ }^{5}$ and promote the concept of human security the UNDP had initiated so as to redefine security away from states and toward individuals and explicitly as an alternative to the US's statesecurity and military focus. Two years later in 2000, however, the Canadian government broke from this developmental focus by convening an International Commission on Intervention and State Sovereignty in the aftermath of its role to make possible the NATO bombing of Serbia in 1999, despite Security Council refusal to authorise it (see Heinbecker 2004). A doctrine of 'humanitarian intervention' articulated for the intervention in support of Kosovo Albanians was then generalised by the Commission report of September 2001 to be an international right and obligation to intervene, if necessary, to protect civilians at risk of massive human rights violations when their own governments would not or could not fulfill their 'sovereign responsibility to protect' their citizens.

This new doctrine of international security, the Responsibility to Protect (R2P), was presented by the UN Secretary-General to the General Assembly for adoption, in what would appear an effort to return an eroding authority over collective security to the UN. Its use of the concept of state failure is distinct from that claimed by the US national security strategy of 2002 in response to the attacks on New York and Washington in September 2001 and the doctrinal basis for the US-led 'global war on terror' (GWOT) beginning in Afghanistan in 2001 and, less successfully at the UN, in 2003 against Iraq. At the same time, however, the contrast with another commission on human security funded by Japan and presented to the UN, which retains the developmental concept of $1994,{ }^{6}$ reveals a shift in practice by US allies in Europe towards a concept of security that has more in common with that of the 'rogue state'. Although all three former allies (Canada, Japan and Norway) on human security became prominent actors in support of the US intervention in Afghanistan, the Canadian initiative prevailed in the next step at the UN, when the 2004 report of the High Level Panel on Threats, Challenges and Change appointed by Kofi Annan, A More Secure World: Our Shared Responsibility (UN 2004), defined collective security in terms of six clusters of threats (one of which is 'internal conflict, including civil war, genocide and other large-scale atrocities') that oblige action on the principle that 'Any event or process that leads to large-scale death or lessening of life chances and undermines States as the basic unit of the international system is a threat to international security'.

\section{Consequences}

Although there remain disagreements within the camp of victorious powers since 1989 about the definition of security, the best use of military power for collective security, and the goal of development aid, I suggest that the trend indicates a noticeable reduction in disagreements in favour of choices made by the USA in 1989-90 to institutionalise its victory in the Cold War and thereby define the succeeding international order. NATO is now a global player and expanding continuously. The concepts of cooperative security and human security and the organisations promoting these alternatives have clearly lost while non-traditional security concerns are struggling for attention. Funds established to facilitate greater policy coherence on security and development, such as the UK Global Fund for Conflict Prevention or Norwegian and Dutch aid for fragile states, are currently being spent overwhelmingly on two cases, Iraq and Afghanistan, and these cases, in turn, are also having a major securitising influence on UN peacekeeping missions and humanitarian operations. Among emerging economic powers in the global South, such as China, India, ${ }^{8}$ and Brazil, there is a noticeable willingness to accept US-defined obligations in global security - being 'responsible stakeholders' in the words of Robert Zoellik when he was US Deputy Secretary of State - based on their own perceived self-interest in the US-led international economic order. This includes assuming regional leadership in managing security threats, whether as states such as Brazil and China or organisations such as the Association of South East Asian Nations (ASEAN), the Organization of American States (OAS) and the AU. 
Against this trend is the growing differentiation in economic and political interests in the South, which does not support a North-South polarity and requires collaboration between Northern states and those Southern states that have economic and political resources to assist in managing global security, on the one hand, and similar security interests as the North against the threat of failed states, spillover from civil wars, nuclear proliferation, and alternative economic agendas, on the other. The same differentiation creates elements of opposition to a US-led Northern agenda, such as the domestic turmoil, declining state capacity, and rising inequality and poverty that many attribute persuasively to the transformative, neoliberal agenda of the USA, IMF, World Bank, and many development donors. Although new regional approaches to these facts either challenge US policy, as that of ASEAN toward Myanmar, or are autonomous of the USA, as those emerging in South America in regard to Bolivia and Venezuela or in Africa to Zimbabwe, for current examples, the lack of US support militarily and financially for UN peacekeeping operations appears still to be sufficient to override reforms provoked by the High-Level Panel report. UN peacekeeping missions were severely underresourced by 2008, particularly in Africa, prompting the outgoing department head to accuse the Security Council of squandering this valuable instrument. ${ }^{9}$ Another instance of opposition to US dominance, but whose implications are more difficult to assess, is the growing anti-USA sentiment, particularly in Islamic countries and populations in reaction to the US war in Iraq and its 'GWOT' military activities, such as bombings in Afghanistan and Pakistan that incur heavy civilian casualties and violate sovereignty norms.

Whether justified in terms of 'rogue states', 'failed states', or R2P, governments in the South in general are also reacting increasingly to these multiplying Northern excuses, in their view, to intervene and remove all barriers to interference in the domestic affairs of a state at will and to instrumentalise the UN for this agenda. The consequence since 2001 has been a defensive, sovereignty-or-bust revival of the principle of non-intervention, even from many states in the South that had been moving toward support for this agenda, whether because they agreed with the values to be protected, had national economic interests more in line with the global North than their neighbours, or had separate national interests in taking on the role of new 'regional powers'. While opposition from governments in Myanmar, Iran, North Korea, and Sri Lanka are currently seen as outliers, the more common expression of this reaction is a rhetorical assertion of the principle of and need for more 'ownership'. In the context of a simultaneous Northern pressure for democracy, however compromised by shifts in US policy between 2001 and 2008, the USA and its allies are less able to dismiss the electoral effects of popular anger generated by their policies, such as the reaction of the new Pakistani government to US military incursions into Pakistani villages in 2008 or the electoral power of Hamas in Palestine, Hezbollah in Lebanon and the indigenous population in Bolivia.

These opposite trends and multiple opportunities to form new political coalitions around new agendas in global security raise the question about where and how alternative leadership might emerge. Two sources of tension are suggestive. On security issues directly is the failure of Western policies of incorporation toward Russia as measured by Russian reaction in 2007-8 against the systematic and repeated dismissal of its views and concerns since 1991. Based on the initial 'allies from within' projection of power by the post-1945 allies - Russia was incorporated economically when the G-7 agreed to become the G-8 and more gingerly in security policy with the creation of the NATO-Russia Council - this policy presumed interests and policy perspectives would follow. Instead, conflicts between Russia and the USA and most European allies began early over the break-up of Yugoslavia in 1991-2. The result was an open clash in 1999 over NATO military intervention in Serbia, which infected economic relations when the USA and the EU claimed that Russian moves to charge global market rates for oil and gas, thus removing Soviet-era subsidies, were a security threat, and pushed Russia into confrontation over the blatant disregard for international law and the role of the UN Security Council, in Russian eyes, in their unilateral recognition of the independence of Kosovo and its destabilising precedent globally (beginning with South Ossetia and Abkhazia). When the latter exploded into violence in the summer of 2008, the western alliance rallied around the US position and NATO remarkably 
fast, despite an initial EU effort to find a more nuanced position that respected both the Georgian (and thus US) and Russian positions. Russia appeared to lose as well in its opposition to eventual NATO membership for Georgia and the Ukraine and with potential Asian allies in Vladimir Putin's effort to formulate a conceptual basis for an alternative global alliance against US militarism and policies on the basis of the Kosovo case. But the Kosovo case, followed by

Afghanistan and Iraq, make clear that the issues of sovereignty and of leadership in global security are not resolved as the victorious powers presumed in 1989-90.

\section{Notes}

* I wish to thank the Ford Foundation for its generous grant to my project on State Failure: Reframing the International Economic and Political Agenda, which made possible the research for this article.

1 The speech concerned the Persian Gulf crisis, in retrospect an iconic moment for eventual change in the global security order.

2 See Chayes (2008) on the consequences.

3 India, Brazil, South Africa.

4 For a comprehensive history and analysis of the concept of human security, see MacFarlane and Khong (2006).

5 This group soon included Austria, Chile, Ireland, Greece, Jordan, Mali, the Netherlands, Slovenia, South Africa, Switzerland and Thailand, under a Canadian label, the Human Security Network (see Suhrke 1999).

6 MacFarlane and Khong (2006: 235) identify this parting of the ways in terms of perceived security threats, between a Canadian focus on

\section{References}

Abrahamsen, Rita (2000) Disciplining Democracy: Development Discourse and Good Governance in Africa, London: Zed Books

Atwood, J. Brian (1994) 'Suddenly Chaos', Washington Post, 31 July: 31

Chayes, Antonia (2008) 'American Treaty Behavior: An Obstacle to National Security?' International Security 32: 4 (Summer)

Chenoy, Kamal Mitra and Chenoy, Anuradha M. (2007) 'India's Foreign Policy Shifts and the Calculus of Power', Economic and Political Weekly XLII.35 (1 September): 3,547-54

Doornbos, Martin (2003) "'Good Governance": The Metamorphosis of a Policy Metaphor',
Second, regarding the economic aspects of global security, in particular the room for alternatives on domestic policy and security alliances, the role of Chinese aid as an alternative to IFI and OECD donor aid in Africa, South-east Asia, and Latin America is already significant, particularly in light of the global financial crisis of 2008. It is this factor especially that demonstrates the fluidity of the current global security order and the substantial bases for alternative political coalitions and outcomes in the future than that which seemed inevitable in 1989-90.

'freedom from fear and violence' and a Japanese focus on 'freedom from want'. For more on the Commission on Human Security, see pp. 157-63.

7 A More Secure World, p. 2; the report was adopted by the UN General Assembly in its World Summit Outcome Document on 25 October 2005; see, in particular, paragraphs 138 and 139.

8 The case of India is particularly instructive, not only because of its decision after almost 60 years of protecting its security independence to sign a bilateral security pact with the USA, but also because the decision by the Communist Party to leave the coalition with the Congress Party in protest made it possible for the government to adopt another round of neoliberal economic reforms in 2008. For a critical Indian analysis of the security treaty, see Chenoy and Chenoy (2007).

9 Harvey Morris, 'Conflict Interventions Push Close to "the Outer Limit of Peacekeeping", Financial Times, 24 July 2008, p. 5.

Journal of International Affairs 57.1 (Fall): 3-18 (reproduced as Ch. 4 in Martin Doornbos (2006) Global Forces and State Restructuring: Dynamics of State Formation and Collapse, London: Palgrave Macmillan)

Duffield, Mark (2007) Development, Security, and Unending War: Governing the World of Peoples, London: Polity

Duffield, Mark (2001) Global Governance and the New Wars: The Merging of Development and Security, London: Zed Books

Fukuyama, Francis (1989) 'The End of History?' National Interest 16 (Summer): 3-18

Heinbecker, Paul (2004) 'Kosovo', in David M. Malone (ed.), The UN Security Council: From the 
Cold War to the 21st Century, Boulder: Lynne Rienner for the International Peace Academy: 537-50

Ikenberry, John (2001) After Victory: Institutions, Strategic Restraint, and the Rebuilding of Order after Major Wars, Princeton: Princeton University Press

Jervis, Robert (2002) 'Theories of War in an Era of Leading-Power Peace', Presidential Address, American Political Science Association, American Political Science Review 96.1 (March): 1-14

Klare, Michael (1998) 'The Rise and Fall of the "Rogue Doctrine": The Pentagon's Quest for a Post-Gold War Military Strategy', Middle East Report 208 (Autumn): 12-15, 47
MacFarlane, S. Neil and Khong, Yuen Foong (2006) Human Security and the UN: a Critical History, Bloomington: Indiana University Press

Panitch, Leo and Gindin, Sam (2004) 'Global Capitalism and American Empire' in Leo Panich and Colin Leys (eds) Socialist Register 2004: The New Imperial Challenge, Monmouth: Merlin Press

Suhrke, Astri (1999) 'Human Security and the Interests of States', Security Dialogue 30.3 (September): 265-76

UN (2004) A More Secure World: Our Shared Responsibility, Report of the Secretary-General's High-level Panel on Threats, Challenges and Change, New York: UN 